\title{
ASSESSING THE PRECURSORS OF POVERTY AMONG FAMERS IN THE SAVANNA ZONE OF CROSS RIVER STATE BEING TETFUND RESEARCH GRANT STUDY
}

\author{
NDIFON AGBOR NDIFON ${ }^{a}$ EMOGOR BASSEY ${ }^{b}$ \\ aabmadu@yahoo.com \\ Department of History Cross River State College of Education, Akamkpa \\ Department of History Cross River State College of Education, Akamkpa
}

\begin{abstract}
Precursors of poverty relate to inherent factors that determine economic and social development of persons. This paper devotes attention to the investigation of these causes in a typical poverty of ravaged region of Nigeria in the Sub-Saharan belt of Africa. Here predominantly, over $80 \%$ of the populations are peasant farmers whose livelihood sustainability are constrained by social and ecological parameters. The paper adopted the approach by isolating the key elements of the social and ecological variable that may contribute to retardation of progress. Following field data acquisition, the data were tested statistically using the chi-square $\left(\mathrm{x}^{2}\right)$ technique of analysis. The results of the two parameters were separately evaluated following the decision rates. From the findings, based on hypothesis I using socio-cultural variables the null hypothesis was rejected and the alternative accepted. Hence there is significant difference in the sociocultural precursor in poverty incidence in the area. Again for hypothesis, II, based on ecological parameters. The null hypothesis was also rejected indicating that there is a significant variable in causing poverty in the area.
\end{abstract}

Keyword:Poverty, Socio-cultural ,Ecological , Farmer

\section{Executive summary}

Deriving from the title of this work "Assessing the precursors of poverty" the general aim and specific objective are clearly embedded. Basically, peasant farmers in different parts of the tropical world are often constrained by certain inherent setbacks that hamper their social and economic development.

Cultural and ecological variables are the strong forces that tend to bedevil their smooth path of growth economically and socially. In this work, these two parameters form the thrust of data analysis that led to the derivation of the findings for the research. The key area of problem identification derived from the precint of cultural and ecological variation that determine the peoples occupation and life forms.

For the essence of indept assessment and the basis of comparative analysis, the scope of this study was expanded to cover the entire cultural paraphenelia of the people. In line with these two hypotheses were formulated for data analysis for the study. 
The area of study is the entire Cross River State, with 18 geopolitical units. These units are politically demarcated into three zones, the north, the central and the south on the political delimitation as senatorial districts.

The population drawn from each local government using peasant farmers as respondents as represented on table 1 below. From the table, a total of 360 peasant farmers respondents were used for data collection using the questionnaire and check list as instruments.

Data was analysed using the chi square $\chi^{2}$ statistical technique and the findings were discussed based on the results according the hypothesis stated. The analysis also focused on the analysis of raw data presented on tables $11 \mathrm{a}$ and $11 \mathrm{~b}$ which were used for testing of hypothesis I and II.

\subsection{Background of the study}

\section{General Overview}

Social inequality is a significant feature of the current human society in the world. From the primitive stage of human existence, properties were shared in common. This period witnessed equity of human status and development. In this period everyone had the right to question how research were shared. In time, this trend changed due to the ability of one group acquiring better tools and technology leading to the group exercising control over the others. Also environmental crises such as crop failure, flood, wind, earth quake and other disasters brought loss of influence by one group against another. This commenced the genesis of slavery and poverty. These phenomena resulted in the transition from communual to fuedal society which witnesed the emergence of land owning class and the landless slaves or serfs. Fuedalism ended with the emergence of industrial revolution which transformed the world from landend class to capitalist ownership of property (Emeh 1996) Cipitalism. Ushered in a new era of sprawling in equalities. Today we speak concerning the rich and the poor citizens of our society. Poverty has many dimension and causes. And it also has well-marked effect on individuals and groups on the basis of sustainable development. Talking generally, the rural communities in Nigeria and other developing nations are associated with poverty while the urban population are identical with wealth and aflluence. Correspondingly the industrialized capitalists nations are epitomes of wealth while the developing nations are domians of endemic poverty. This research endevour focuses or directed attention to issues of rural poverty in Cross River State.

\subsection{Statement of the problem}

The problem identification derives from the prevailing scenarios observed in the societies under consideration. In developmental analysis there are general direct and surrogate measures that are employed in the explanation of wealth or poverty.

In certain instances, the parameters used in capturing the essence of poverty or wealth may be illusory in the ingrained assessment. The result at the basic level of analysis of Africa in general and Nigeria in particular. The problem statement of this study derives from the answered puzzle of the principal elements of the physical and social environments that were aggravating the malaise of poverty in the region. This understanding will provide insights on the relevant approaches that will be adopted in mitigating or curbing the menace in the area under investigation.

\section{3 Research aims and objectives}

\section{Aim of the research:}

This research is generally directed at investigating the principal cause's poverty among peasant farmers in the rural communities of Cross River State, Nigeria. 


\subsection{Research objectives.}

From the above stated aim, two specific objectives were stated for the study as follows.

- To investigate the relationship between incidents of rural poverty and the people's life form and culture in the study area.

- To investigate the relationship between incident of rural poverty and ecological conditions or parameters in the area.

\subsection{Research hypothesis:}

Strictly in line with the stated objectives above two research hypotheses were formulated in null and alternative forms as follows:

\section{Hypothesis I}

$\mathrm{H}_{\mathrm{O}}$ : The peoples life forms cultural attributes do not significantly contribute to poverty among peasant farmers in the rural communities of cross river state, Nigeria.

$\mathrm{H}_{\mathrm{I}}$ : The people's life forms or sociocultural attributes do contribute significantly to poverty among peasant farmers in the rural communities of cross river state, Nigeria.

\section{Hypothesis II}

$\mathrm{H}_{\mathrm{O}}$ : Ecological conditions do not contribute significantly to poverty among peasant farmers in the rural communities of Cross River State, Nigeria.

Hi: Ecological conditions do contribute significantly to poverty among peasant farmers in the rural communities of Cross River State, Nigeria.

\subsection{Scope of the study}

Geographically, the study covers the entire cross river state of Nigeria. In terms of ecological variation the state comprises the forest south and the savanna north.

Conceptually the study devoted attention to the prevalence of poverty such as Social cultural parameters ecological parameters, and economic parameters. Granted that economic parameters are predicates of socio culture and ecological parameters, attention was focused more on the two previous ones.

Sources of data: Only primary source data were utilized for the study. This involved employment of the questionnaire and the check list for field data capturing.

\section{LITERATURE REVIEW}

\subsection{Conceptual explanations.}

\subsection{The concept of poverty}

Poverty has amorphous explanations of meanings. At first sight it connotes absolute deprivation and lack of material means. Poor people generally are seen as the powerless, voiceless and vulnerable lots. Their vulnerability is seen in their inability to adapt to changing social and ecological trends. The poor are seen to be economically, politically, culturally and educationally stagnated (Cakubiro, 2014). All manner of uncomplimentary accolades ascribed to the poor. However some scholars have tended to tend colour to the meaning and explanation of poverty within the precint of their domain. Aluke (2011) advocate that poverty explains the one who lacks adequate financial resources within the context of a society's financial or fiscal environment.

This was clearly substantiated by Shaefur (1996) who differentiated material poverty, psychological poverty, knowledge poverty, social poverty and perceptual poverty. In Nigeria and most developing countries, poverty of the various categories are rampant or prevalent. We can also briefly turn attention to the general status of poverty in Nigeria vis-à-vis Cross River State. 


\subsection{Status of poverty in Nigeria}

In a world bank report (2018), Nigeria had surpassed India as a nation with the highest number of people living in extreme poverty across the world with an estimated 86.9 million Nigerians measured to be living on less than and 1.90 ( $\$ 684$ ) a day. A recent report from the world poverty clock, the figure has increased to 93.7 million in 2019.

A further report from the World Bank (2018) more than half of Nigerians population lives on less than a dollar a day. To further corroborate this, the world data lab noted that the outlook for poverty alleviation in Nigeria is weak and that an estimated 120 million Nigerians are expected to slip into extreme poverty 2030.

Ironically, at the global scale, the picture is significantly different but inherently there are more rural poor than urban poor. This situation is squarely replicated in the cross river situation where rural areas constitute more than $80 \%$ of the total land mass of the state with predominantly peasant farmers. This brings in the assumption of precursors of rural poverty which informs the problem definition of this work.

\section{- The city ecological foot print perspectives and rural underdevelopment.}

Urban geographers in Nigeria in the persons of Mabogunje (1985) Ojo (1989) and Udo (1992) have provided cogent explanations as the roots of urban underdevelopment of the rural areas in Nigeria. The lopsided relationship which is explained based on the nature of rural -urban interaction is what had been described by David, Miltin and Satharativiate as "the cities ecological foot print." This is simply explained to mean the extent to which a city draws its resources from the surrounding country sides.

By this means, the city grows at the expense of the rural areas by tapping the materials and human capital for its development without correspondingly replacing it in another form. Essentially the pre and post colonial Nigeria urban areas grow by exploiting the available rural resources for their development. Clearly started, urban market is feed by rural country sides. Industrial raw materials are derived from the rural areas in the form of wood, hides and skins, and so on.

More poignantly, the virile youths population are drawn from the rural areas to feed the urban industries and other service occupations. Most of the rural -urban migrates from the rural domains move in search of employment that are few and far between. Because the urban centers are not sufficiently generative (Mabogunte 1978) it leads to the grave problem of urban unemployment. Mass migration to the urban areas leads to over-population of the urban centre and under population of the rural areas. While the urban centers suffer labour glut, rural areas suffer rural underutilization of its resources.

A second dimension to the issue of rural-urban imbalance derives from the nature of colonial education received from the colonial administration. The curriculum of the colonial pedagogical learning emphasized literacy, numeracy without thinking and problem solving. (Anni 2002). In the express notion of Anni (2002) the sole aim of the colonial masters was to teach the black Nigeria to learn not to reason independently but dependently. It follows then that colonial form of frictional. Less emphasis was on technical education or enterprise exation learning. This introduced civil service dependency, where other occupations are seen as less lucrative.

\subsection{Disparity in rural urban infrastructure}

Rural poverty is clearly epitomized in the above phrase "disparity infrastructure". This concept was captured in a statement of an International Conference on "expo 2000" by a one-time director general of the United Nations Environmental Programme(UNEP) in the clause "Towns and rural areas are growing apart". Basing this argument on disparity on communication infrastructure he said while the town worked with the internet, on the land there was mostly not even a telephone in the rural areas.

Further on, stated that while many towns were interwinning there was not even a rural partnership, this agrees with an earlier premise by Gould and White 1974 in their mental maps that while the information surface is high in the urban area ignorance surface as corresponding high in the rural areas. This causes the high preference matric of the mental maps of the rural- urban development nexus. Poor networks, lack of basic and social amenities, poor educational facilities in terms of infrastructure and teaching personnel, and other development paraphernalia are the glaring spectacles of urban-rural imbalance which creates rural 
underdevelopment and poverty. The marked demarcation presents disillusionment and lack of attractiveness of rural place thereby leading to mass migration to areas of green pastures, the urban centre

The problem of agriculture is another over bearing concern. A food and agricultural organization (FAO) study (2016) showed that the productivity of rural agriculture was declining by $10 \%$ annually in the tropics and Nigeria in particular soil improverishment, soil erosion, lack of farm innovation and other similar tapes in systems organization have all concluded to the nature of the declaiming rural agricultural productivity.

\subsection{Some Specific Causes of Rural Poverty}

The previous section devotes attention to some general essence of the status of rural-urban imbalance. Here attention is being turned to some particular circumstance of the roots of rural poverty.

A few of these have been explored in the literature and briefly highlighted below:

- Lack of good job or under employment: When one lacks a regularly paid job or secure employment the income level of the individual with not be stable. Following a report from economic policy institute (2020) large groups workers with full-time year-round employment are still below federal poverty guidelines. Also in some countries like the democratic republic of Congo, most of the people live in rural areas slipped of natural resources, similarly in the savanna belt of Africa generally seasonal unemployment is a grave reason for rural poverty where most peasant farmer's remain idle in the dry season without productive activity (Grove 1978)

- Inadequate or functional education: Illiteracy is gave milody in all developmental analysis. People without education wallow in ignorance and poverty. Being uninformed they remains economically, socially and developmentally deformed. Following a UNESCO declaration (2005) over 170 million people could be free of extreme poverty, if only they had basic reading skills. Inadequate capital, distance travelled to school and other related factors account for the large population of illiterate persons in the rural areas of Cross River State Nigeria.

- Weather and climate change: Following a World Bank report (2018) climate change has the tendently to impoverish 100 million people in the next decade. The report started that climate change causes drought, flood and severe storms. It states further that recovery is extremely difficult especially for agricultural communities where they barely have enough to feed themselves. In the rural communities of Cross River State, Nigeria, vagaries in the weather regime due to delayed commencement of rainy season, or early cessation of rainfall and other uncertainties in the weather egimes have led to dramatic loss of from crops and crop yields generally. In this year's farming seasons, rice farmers in the savanna zone have colossally experienced crop failures due to sporadic rainfall regime. Nigerian meteorological services Annual review (2012)reports adverse weather events in different parts of the country portrayed gloomy picture for farmers.

- All and sundry: Numerous explanations to the causes of poverty have been provided in the literature. Sundry other causes are provided in broad outlines as follows:

- Social in justice

- Inadequate infrastructure

- Inadequate government employment

- Inadequate health care delivery

- Inflation/highest of living

\subsection{Summary of Review.}

The review explored wide range of issues predicated on rural poverty generally. The root causes of urban-rural imbalance were careful examined. Also the status of rural poverty was considered.

Finally, numerous caused of poverty in general were brought forward from the literature. It is therefore hoped that this submission will throw light on the essential precursors of rural poverty of peasant farmers in cross river state Nigeria.

Economic and livelihood parameters are therefore used as surrogate measured to electricity information 
to explain the basis of poverty in the area.

\section{Area of study:}

The study area is cross river state of Nigeria. It is one of the 36 geopolitical entities that made up of the 36 federal states of the reaction Nigeria. The states comprises 18 geopolitical units or local government delimitations. A broader geopolitical demarcation splits the state into north, central and south senatorial districts.

Ecologically, the state has two broad ecological biomes, the forest south and the savanna north. These demarcations find their basis on the climate and vegetational parameters that provide the unique identities of two regions. Higher relative humidity, higher vapour transportation and correspondingly higher rainfall create opportunity for development of tropical rainforest which were the prestrike vegetation of the forest or south. Currently only vestiges or these are left due to human activities in agriculture, lumbering and soon.

\section{Method of study}

Study Design: This study is a field explorating focused on data collection using the question and check list instrument for editing information from the field. The question is administered to the sampled population of the study checkouts were used as observation instrument for data capturing the relevant surrogate parameters from the field. Surrogate measure are those indices that depict the essence of poverty in an area such as housing equality, social characteristics life modes and life styles environmental equality etc.

The savanna north is climatically characterized by relatively lower humidity less evapotranpirative and less incidence of rainfall, prolonged dry spells of drought or avidity is a significant feature of the savanna ecotone. The vegetation is predominantly grassland end woodland park savanna. The people's occupation status follows closely the regime of weather and climate. The forest south engages mostly in stabilized crop cultivation and scquacullire while the savanna north engages more in arable formatting and livestock undertakings. Also in line with the ecological differences, the cultural attributes are correspondingly variegated.

\section{Study population:}

The population involved adult male and female residents in rural communities of Cross River State. The population was also restricted to male and female residents who were of regular households and correctly in coherent family hood. Single male and female residents were not captured in the interview procedure.

\section{Sampling technique:}

Multi-stage sampling procedure was used in the selection of the population for the study $5 \%$ sample size was employed.

Purposive sampling techniques was employed on the basis of the geopolitical units. North, central and south senatorial district respectively from the three senatorial districts, two local government areas each were selected. This the total number of L.G.A used for the study were six out of the eighteen L.G.A that constitute the stage from each L.G.A two rural communities were selected for data collection. 12 rural communities that were utilized for the study from each of these $5 \%$ male and female presently married persons ware random by selected for the study. The 5\% randomly selection produced variegated numbers according to the relative's numbers of the adult married persons as shown by table 1 below.

\section{Instrument used in data:}

Political maps were used in declined areas for data collection. Global positioning systems were employed in weathering areas in terms of co-ordinates of location. 


\section{Socio-cultural parameters:}

Reponses are to elicited based on a four point rating scale techniques as follows.

$\mathrm{A}=\mathrm{AGREE}, \mathrm{SA}=$ Strongly Agree, $\mathrm{D}=$ Disagree and $\mathrm{SD}=$ strongly disagree .

Table 1: Socio-cultural precursors of poverty (Hypothesis I)

\begin{tabular}{llllll}
\hline RESPONSE ITEMS & A & SA & \multicolumn{1}{c}{ D } & SD & TOTAL \\
\hline 1. I Enjoy social outings & 123 & 109 & 93 & 22 & 330 \\
\hline 2. Hug outlay of money is spent in burial & 114 & 132 & 85 & 25 & 354 \\
\hline 3. Family size is quite large & 121 & 115 & 118 & 13 & 353 \\
\hline 4. Land tenure system tingles development & 106 & 121 & 78 & 61 & 353 \\
\hline 5. Government land is appropriate is common & 77 & 62 & 98 & 109 & 346 \\
\hline 6. There is incidence of frequent inter-communal areas & 106 & 122 & 62 & 98 & 358 \\
\hline 7. High bridal price ceremony is common in my area & 98 & 76 & 111 & 71 & 356 \\
\hline
\end{tabular}

Table 2

Ecological percusors of poverty (Hypothesis II)

RESPONSE ITEMS

Early cessation or delay in seasonal reversal affects our

$\begin{array}{lllll}\text { A } & \text { SA } & \text { D } & \text { SD } & \text { TOTAL }\end{array}$

farm productivity

\begin{tabular}{llllll}
\hline Excessive rainfall is a menace to agric productivity & 105 & 110 & 80 & 55 & 350 \\
\hline Drought incidence is a common feature of your area & 98 & 94 & 115 & 122 & 357 \\
\hline Incidents of pests disease affect our crops and livestock & 102 & 96 & 109 & 49 & 358 \\
\hline Poor soil status affect our crops productivity & 108 & 115 & 103 & 31 & 357 \\
\hline Soil erosion incidence is a major constant & 118 & 108 & 86 & 42 & 354 \\
\hline Hard pan formation/ certification affect land development & 93 & 119 & 72 & 70 & 354 \\
\hline Flood incidence is a major constrain to development & 126 & 108 & 74 & 48 & 356 \\
\hline $\begin{array}{l}\text { Cully erosion is common or prevalent in our area } \\
\text { Burial ceremonies take a huge toll of our income }\end{array}$ & 114 & 96 & 72 & 81 & 353 \\
\hline $\begin{array}{l}\text { Frequent incidence of holidays/pastime is common in our } \\
\text { culture }\end{array}$ & 127 & 127 & 94 & 12 & 356 \\
\hline $\begin{array}{l}\text { Farm innovation is not readily adopted in our farming } \\
\text { systems. }\end{array}$ & 136 & 128 & 72 & 23 & 357 \\
\hline
\end{tabular}

\section{Method of data analysis}

Data will be analysed using the method of chi-square $\left(\mathrm{x}^{2}\right)$ analysis for the population under study.

Data presentation and analysis

Data is presented in line with the variable employed for the study as follows: 
Samples population by Local Government. Twenty respondence were randomly samples per each of the Eighteen L.G.A as represented in table $i$ below.

Table 3: Reponses population by L.G.A

\begin{tabular}{|l|l|c|}
\hline \multicolumn{1}{|c|}{ ZONE } & L.G.A & RESPONTENTS POPULATION \\
\hline NORTHERN ZONE & OBANLIKU & 20 \\
\hline & OBUDU & 20 \\
\hline & BEKWARA & 20 \\
\hline & OGOJA & 20 \\
\hline & YALA & $\mathbf{2 0}$ \\
\hline & TOTAL & $\mathbf{1 0 0}$ \\
\hline & & 20 \\
\hline & BOKI & $\mathbf{2 0}$ \\
\hline & IKOM & $\mathbf{2 0}$ \\
\hline & ETUNG & $\mathbf{2 0}$ \\
\hline & OBUBURA & 20 \\
\hline & YAKURR & $\mathbf{2 0 - 8}=120$ \\
\hline SOURTHERN & TOTAL & $\mathbf{2 0}$ \\
\hline & & $\mathbf{2 0}$ \\
\hline & BIASE & $\mathbf{2 0}$ \\
\hline & AKAMKPA & $\mathbf{2 0}$ \\
\hline & ODUKPANI & $\mathbf{2 0}$ \\
\hline & CAL NORTH & $\mathbf{2 0}$ \\
\hline & CAL SOUTH & $\mathbf{2 0}$ \\
\hline & AKPABUYO & $\mathbf{1 4 0}$ \\
\hline & BAKASSI & \\
\hline & TOTAL & \\
\hline
\end{tabular}

GRANDS TOTAL: 360 RESPONDEENTS

Ecological parameters (Hypothesis II) here also response are to be based on a four point rating scale. Techniques e.g. 
Data analysis

Table 4:Chi square table on sociocultural precursors of poverty(Hypothesis I)

\begin{tabular}{|c|c|c|c|c|}
\hline$O_{i j}$ & $E_{i j}$ & $\left(O_{i j}-E_{i j}\right)$ & $\left(O_{i j}-E_{i j}\right)^{2}$ & $\frac{\left(O_{i j}-E_{i j}\right) 2}{E_{i j}}$ \\
\hline 123 & 100 & 23 & 529 & 5.2900 \\
\hline 109 & 107 & 2 & 4 & 0.9373 \\
\hline 93 & 83 & 10 & 100 & 1.2048 \\
\hline 22 & 37 & -15 & 225 & 6.0811 \\
\hline 114 & 103 & 11 & 121 & 1.1748 \\
\hline 132 & 110 & 22 & 484 & 4.4000 \\
\hline 85 & 85 & 0 & 0 & 0.000 \\
\hline 25 & 38 & -13 & 169 & 2.8684 \\
\hline 121 & 106 & 15 & 225 & 2.1226 \\
\hline 115 & 114 & 1 & 1 & 0.0688 \\
\hline 118 & 88 & 30 & 900 & 10.227 \\
\hline 13 & 40 & -27 & 729 & 18.225 \\
\hline 106 & 105 & 1 & 1 & 0.0095 \\
\hline 121 & 113 & 8 & 64 & 0.5637 \\
\hline 78 & 87 & -9 & 81 & 0.9210 \\
\hline 61 & 38 & 23 & 529 & 13.921 \\
\hline 77 & 100 & -23 & 529 & 5.290 \\
\hline 62 & 107 & -45 & 2025 & 18.925 \\
\hline 98 & 83 & 15 & 225 & 2.7108 \\
\hline 109 & 37 & 72 & 5184 & 140.108 \\
\hline 106 & 103 & 3 & 9 & 0.0874 \\
\hline 122 & 111 & 11 & 121 & 1.0901 \\
\hline 105 & 85 & 20 & 400 & 4.7058 \\
\hline 25 & 39 & -14 & 196 & 5.0256 \\
\hline 98 & 103 & -5 & 25 & 0.2427 \\
\hline 76 & 110 & -34 & 1156 & 10.509 \\
\hline 111 & 85 & 26 & 676 & 7.9500 \\
\hline 71 & 38 & 34 & 1156 & 30.421 \\
\hline 123 & 103 & 20 & 400 & 0.8834 \\
\hline 127 & 110 & 17 & 289 & 2.6272 \\
\hline 94 & 85 & 9 & 81 & 0.8617 \\
\hline 12 & 38 & -26 & 676 & 17.789 \\
\hline 127 & 103 & 24 & 576 & 5.5922 \\
\hline 112 & 110 & 2 & 4 & 0.0364 \\
\hline
\end{tabular}




\begin{tabular}{lllll}
95 & 85 & 10 & 100 & 1.1764 \\
23 & 38 & -15 & 225 & 5.5728 \\
136 & 103 & 33 & 1089 & 10.578 \\
128 & 111 & 17 & 289 & 2.6036 \\
72 & 85 & -13 & 169 & 1.9882 \\
22 & 39 & -17 & 289 & 7.4102 \\
Total & & & & $\mathbf{3 5 2 . 1 9 9 5}$ \\
\hline
\end{tabular}

\section{Decision rule:}

The degree of freedom $(\mathrm{R}-1)(\mathrm{C}-1)=(10-1),(4-1)=(9,3)$ At $\alpha=0.05$ level of significant and degree of freedom 9,3. A table value of $\chi^{2}(0.05,4,3)=3.33$, and 0.352 , if the computed $\chi^{2}$ is $>$ the table $\chi^{2}$ we reject the null hypothesis or otherwise if $\chi^{2}>3.33$ or $\chi^{2},<0.532$

Table 5: Chi square table on Ecology precursors of poverty(Hypothesis II)

\begin{tabular}{|c|c|c|c|c|}
\hline$O_{i j}$ & $E_{i j}$ & $\left(O_{i j}-E_{i j}\right)$ & $\left(O_{i j}-E_{i j}\right)^{2}$ & $\frac{\left(O_{i j}-E_{i j}\right) 2}{E_{i j}}$ \\
\hline 84 & 104 & -20 & 400 & 3.8461 \\
\hline 63 & 100 & -37 & 1369 & 13.69 \\
\hline 100 & 80 & 20 & 400 & 5.000 \\
\hline 110 & 62 & 48 & 2304 & 37.1613 \\
\hline 105 & 102 & 3 & 9 & 0.0882 \\
\hline 110 & 98 & 12 & 144 & 1.4693 \\
\hline 80 & 78 & 2 & 4 & 0.59016 \\
\hline 55 & 61 & -6 & 36 & 0.59016 \\
\hline 98 & 125 & -27 & 729 & 5.832 \\
\hline 94 & 120 & -26 & 676 & 5.6333 \\
\hline 115 & 96 & 19 & 361 & 3.7604 \\
\hline 122 & 75 & 47 & 2209 & 29.4533 \\
\hline 102 & 104 & -2 & 4 & 0.0384 \\
\hline 96 & 100 & -4 & 16 & 0.1600 \\
\hline 109 & 80 & 29 & 841 & 10.5125 \\
\hline 49 & 62 & -13 & 169 & 2.7250 \\
\hline 108 & 104 & 4 & 16 & 0.15384 \\
\hline 115 & 100 & 15 & 225 & 2.2500 \\
\hline 103 & 80 & 23 & 529 & 6.6125 \\
\hline 31 & 62 & -31 & 961 & 15.500 \\
\hline 118 & 103 & 15 & 225 & 2.1844 \\
\hline 108 & 99 & 9 & 81 & 0.8181 \\
\hline 86 & 79 & 7 & 49 & 0.62025 \\
\hline 42 & 62 & -20 & 400 & 6.4162 \\
\hline
\end{tabular}




\begin{tabular}{lllll}
106 & 103 & 3 & 9 & 0.0873 \\
113 & 99 & 14 & 196 & 1.9797 \\
81 & 80 & 1 & 1 & 0.0125 \\
55 & 62 & -1 & 49 & 0.7903 \\
93 & 103 & -10 & 100 & 0.9708 \\
119 & 99 & 20 & 400 & 4.0404 \\
72 & 79 & -7 & 49 & 0.62025 \\
70 & 62 & 8 & 64 & 1.03225 \\
126 & 104 & 22 & 484 & 4.6538 \\
108 & 100 & 8 & 64 & 0.6400 \\
74 & 80 & -6 & 36 & 0.4500 \\
48 & 62 & -14 & 196 & 0.0509 \\
114 & 43 & 71 & 5041 & 117.2325 \\
96 & 99 & -3 & 9 & 0.09090 \\
32 & 79 & -17 & 49 & 0.6202 \\
81 & 62 & 19 & 36 & 5.88225 \\
$\chi^{2}$ & & & & $\mathbf{2 9 4 . 2 5 9 5}$ \\
\hline
\end{tabular}

\section{Decision rule:}

The degree of freedom $(\mathrm{R}-1)(\mathrm{C}-1)=(10-1),(4-1)=(9,3)$ At $\alpha=0.05$ level of significant and degree of freedom 9,3. A table value of $\chi 2(0.05,4,3)=3.33$, and 0.352 , if the computed $\chi^{2}$ is $>$ the table $\chi^{2}$ we reject the null hypothesis or otherwise if $\chi^{2}>3.33$ or $\chi^{2},<0.532$

\section{Hypothesis I:}

$\mathrm{H}_{\mathrm{O}}$ : Socio-cultural attributes do not contribute significantly to intendants of poverty in the rural areas of Cross River State.

$\mathrm{H}_{\mathrm{I}}$ : Socio-cultural attributes do contributes significantly to incidents of poverty in the rural areas of Cross River State.

\section{Hypothesis II}

$\mathrm{H}_{\mathrm{O}}$ : Ecological conditions do not contribute significantly to incidents of poverty in the rural areas of Cross River State.

$\mathrm{H}_{\mathrm{i}}$ : Ecological conditions do contribute significantly to incidents of poverty in the rural areas of cross river state'

Tables I II above were employed for analysis of the hypothesis.

\section{Results and findings}

The two hypotheses were focused on analysing two key parameters to the prevalence of poverty among peasant famers in the state. Sociocultural parameters explored the peoples life attributes, while ecological parameters focused on environmental constraints to development

From hypothesis I which analysed the sociocultural attributes of the population and its relation poverty, the decision rule favoured the rejection of thee null hypothesis which do not contribute significantly to prevalence of poverty in the area. Hence, the alternative hypothesis is accepted indicating that socicultural attribution contribute significantly to prevalence of poverty in the region. This result lends credence to earlier studies on rural poverty such as that by Mabogunje (1985) Ojo (1989) and Ubo (1970) on the basis of rural urban imbalance and rural underdevelopment generally. 
Similarly, David, Mittin and Satterthwaite postulates on "urban ecological foot prints" finds adequate relevance to the findings of the study.

In the same vien, UNEPS Director General (2000) deliberation of the essence of education in rural development is worthy of inclusion in the explanation of this result. To reiterate a paraphrased version of the UNEP'S Boss view, the towns and rural areas are growing apart" again the FAO(2016) study pointed to the reality of rural agricultural productivity decline

Recently a gross assessment of rural poverty analysis presents a gory specticle of how rural life style among the rural folks home contributed to grass underdevelopment in the area

Lavish expenditures on ceremoneys, burials, marriages and festival are common stock in trade among the country folks. Equally unemployment rate is quite high as explained by the world economic data lab.

\section{Hypothesis II}

The analysis of hypothesis II using the same technique of chi square $\left(\chi^{2}\right)$ focused on explanation of rural poverty on the basis of ecological variables or environmental parameters. At 0.05 level of significance the null hypothesis is rejected and the alternate upheld. This means that there is a significant contribution of ecological parameters to incidence of poverty in the study area. Copious literature exist in support if this findings as can be general from a few of the cases cited in this study such is the world bank (2018) report which states that climate change will impoverish over 100 millions people in the next decade. The report went further to state that climate change causes drought, flood and severe storms and recovery is especially difficult for agricultural communities where they barely have enough to feed themselves. This is currently evident in Cross River State where the effect is varigated as caused of the aexial variation in ecological parameters. In current year 2021, the northern savanna zone came under a severe dry spell of weather which resulted in the alteration planting season for rice, yam and cassava, the yield predicited on this poor weather was abysmally poor and most families are experiencing famine and starvation.

Rice yield was grossly affected across all the rice planting communities of the north savanna zone the forest south has its fare-share of the change impact. Over bearing flood incidence leading to destruction of farm crops and displacement of homes. In Akamkpa Cross River State in particular, flood event occurred on the $30^{\text {th }}$ of September this year leading to displacement of people and destruction of form cross and destruction of domestic properties. The Nigerian metrorogical services its yearly review has capatured the magnitude of damage caused by flood incidence on annual basis across the country. Flood damage can be far reaching and impacting in that its recovery is difficult as earlier stated by the world bank report

Becides drought and flood affects, other vagaries such as soil erosion, soil improverishment, soil acidification, hard pan formation and other such ecological effect are common features of rural communities ecology.

The matter is made worse by the fact that farmers coping strategies is limited as result of economic incapacitation, low level technology, low education and conservative ideals of the rural population.

\section{Conclusion}

The result of the findings is this paper reveal that there is currently entrenched poverty among peasant farmers in Cross River State Nigeria, most families live below the normal poverty line of I dollar per day. Social life styles are inherently contributory to poverty agravation due to misplacement of priorities. Ecological factors also have a far-reaching impact. Given the present economic environment, the unrenabling political environment, inadequate education and the low level of education, the situation is likely to aggravate in the near future. There is therefore need for whole rural people re-orientation, mobilization and empowerment in order that positive change could be introduced toward adequate mitigation, adaptation or a adjustment by the rural farmers. 


\section{References}

Akubiro, A.E. 2014. Macro Economic Analysis Poverty Prevalence; The third world perspective of young Economist "Calabar Nigeria."

Aluke, TM. 2011. Economic development for Africa, Emigu, fourth dimension publishers.

Danduri, A.H. 2008. Rural Poverty in Nigeria: Zonal Analysis of Geographic Spreads of Economic Welfurism.

World Bank 2018. On the status of Poverty of in rural areas, contained in the Report on World Bank among Study in Africa development, Washington D.C U.S.A.

Sheafer 1996. Rural-urban Imbalance, a Global review in the Sociology.A brief introduction New York, Earth Publication.

Anni S.E 2002. Authentic education for Nigeria in the $21^{\text {st }}$ century Enugu, Fourth dimension Public

Mabogunje A. L .1978. Urbanization process in Nigeria, the question of rural imbalance. Lead payer presented in the forum of the Nigeria Geographical Association Ibadan, Nigeria.

Mabogunje, A.L 1985. Planning in Nigeria; the questions of slim development and urban live ability.In the proceeding of the association of Nigeria geographical association, universal Lagos.

Udo, R.K 1972. Geographical regions of Nigeria (HTH Editing) Ibadan, Macmillan publications.

Ojo, A.F. 1989. Populations issues in rural-urban Migration in Nigeria. A Seminal prayer on Issues of unemployment in the urban centers in Nigeria.

Toplar, K. 2000. Opening speech in expo 2000 by the director general of the United Nations Environmental Program on the concept of "Global dialogue held in hawwa Ceremony, October 2000.

Could, P and White, R 1994. Mental maps New York, Perigee Publications.

Food and Agricultural organization of the united nations, Rome (2019) Annually Agricultural systems review. In the Journal of Agricola, 5 (1) 145-160.

Economic Policy Institute 2020. Poverty and job security. Global analysis.Grove A.T. (1978) Rural Africa, London Macmillan.

UNESIO 2005. Education and Economics empowered. Third world review.Quarterly report on the sub Saharan region.

David, Mitlin and Satterthwaite 1992 .Evironmental problem in third word cities. New York. Earthscan Publications

Emeh.E.U. 1996. Dictionary of Environmental Education, Calabar, Index publication.

Grove, A.T. 1978. Rural Africa, Ibadan, Macmillan Publishers 